\title{
MRS Publishes First Proceedings Volumes
}

The first four proceedings volumes published by MRS were on display in April at the 1985 Spring Meeting in San Francisco, and four additional volumes in the series were published in May. The proceedings, coming out of symposia conducted at the 1984 MRS Fall Meeting last November, is a milestone accomplishment of the Society, and is a result of months of work by the 1984 Publications Committee, chaired by John Baglin, 1984 MRS President Woody White, 1985 MRS President Elton Kaufmann and MRS Executive Director John Ballance.

The decision to publish the proceedings through MRS Headquarters, rather than through a commercial publisher, has enabled the Society to cut costs to members as much as $30 \%$ and resulted in accelerated production of the volumes. More rapid publication was a primary goal of the Society, so that timely research would be made available to the scientific community as soon as possible.

The first books in the series, published in mid-April are: Layered Structures, Epitaxy, and Interfaces (edited by J. M. Gibson and L. R. Dawson), Plasma Synthesis and Etching of Electronic Materials (edited by R. P. H. Chang and B. Abeles), Electronic Packaging Materials Science (edited by E. A. Giess, K.-N. Tu, and D. R. Uhlmann), and Energy Beam-Solid Interactions and Transient Thermal Processing/1984 (edited by D. K. Biegelsen, G. A. Rozgonyi, and C. V. Shank).

The next four volumes completed in May are: Impurity Diffusion and Gettering in Silicon (edited by R. B. Fair, C. W. Pearce, and J. Washburn), Advanced Photon and Particle Techniques for the Characterization of Defects in Solids (edited by J. B. Roberto, R. W. Carpenter, and M. C. Wittels), Very High Strength CementBased Materials (edited by J. F. Young), and Scientific Basis for Nuclear Waste Management VIII (edited by C. M. Jantzen, J. A. Stone and $R$. C. Ewing). The remaining two volumes, High Temperature Ordered Intermetallic Alloys (edited by C. C. Koch, C. T. Lui, and N. S. Stoloff) and Fly Ash and Coal Conversion By-Products: Characterization, Utilization and Disposall (edited by G. J. McCarthy and R. J Lauf) are scheduled for completion in June.

Individuals, libraries, and other institutions that are planning to purchase each new volume in the series should contact MRS Headquarters for information on how to save money by establishing a standing order account. Contact Mary Kaufold, Publications Department, 9800 McKnight Road, Suite 327, Pittsburgh, PA 15237; telephone (412) 367-3003.

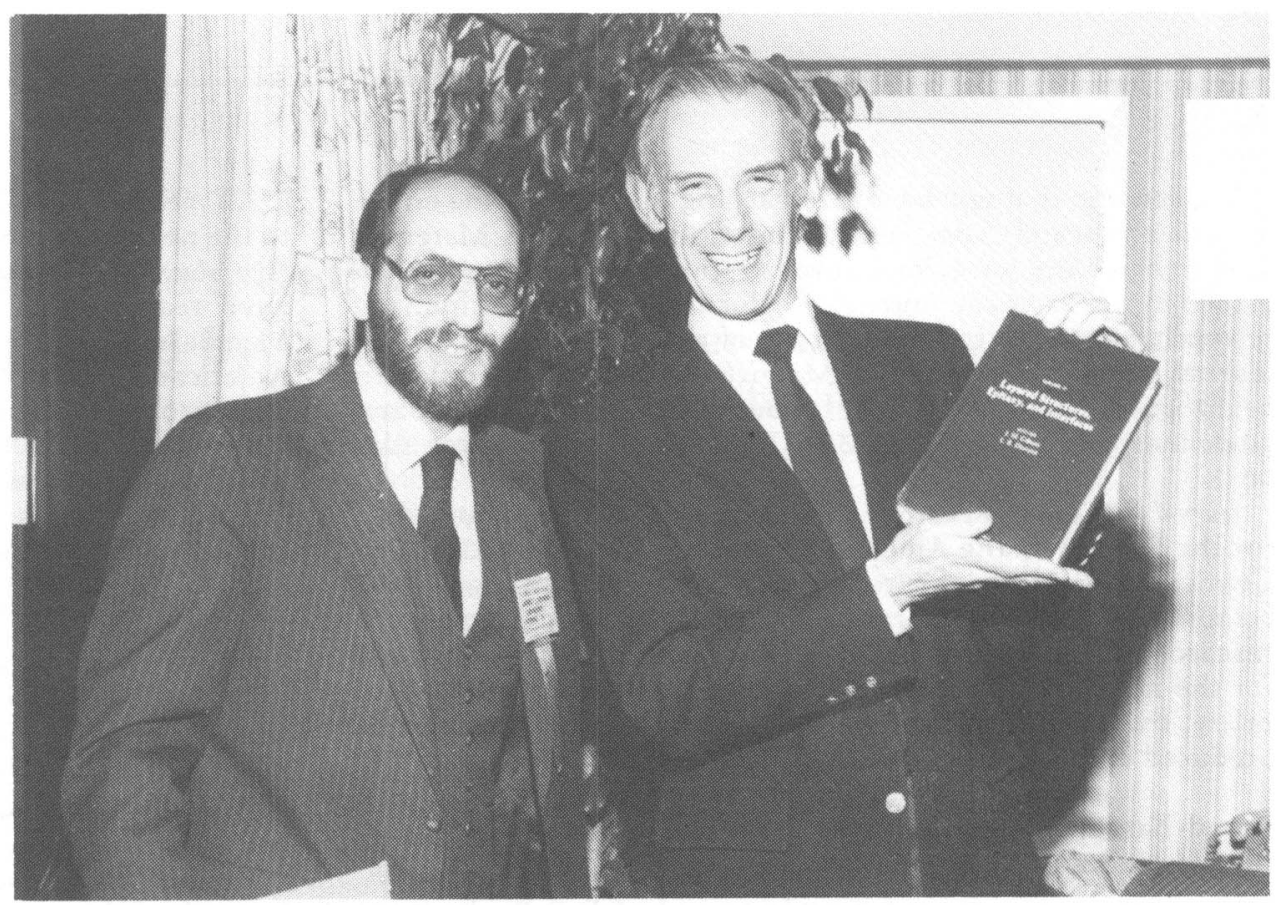

Elton Kaufmann presents a copy of one of the first MRS proceedings volumes to 1984 Publications Committee Chair John Baglin, in recognition of his role in establishing the publications operation at MRS Headquarters.

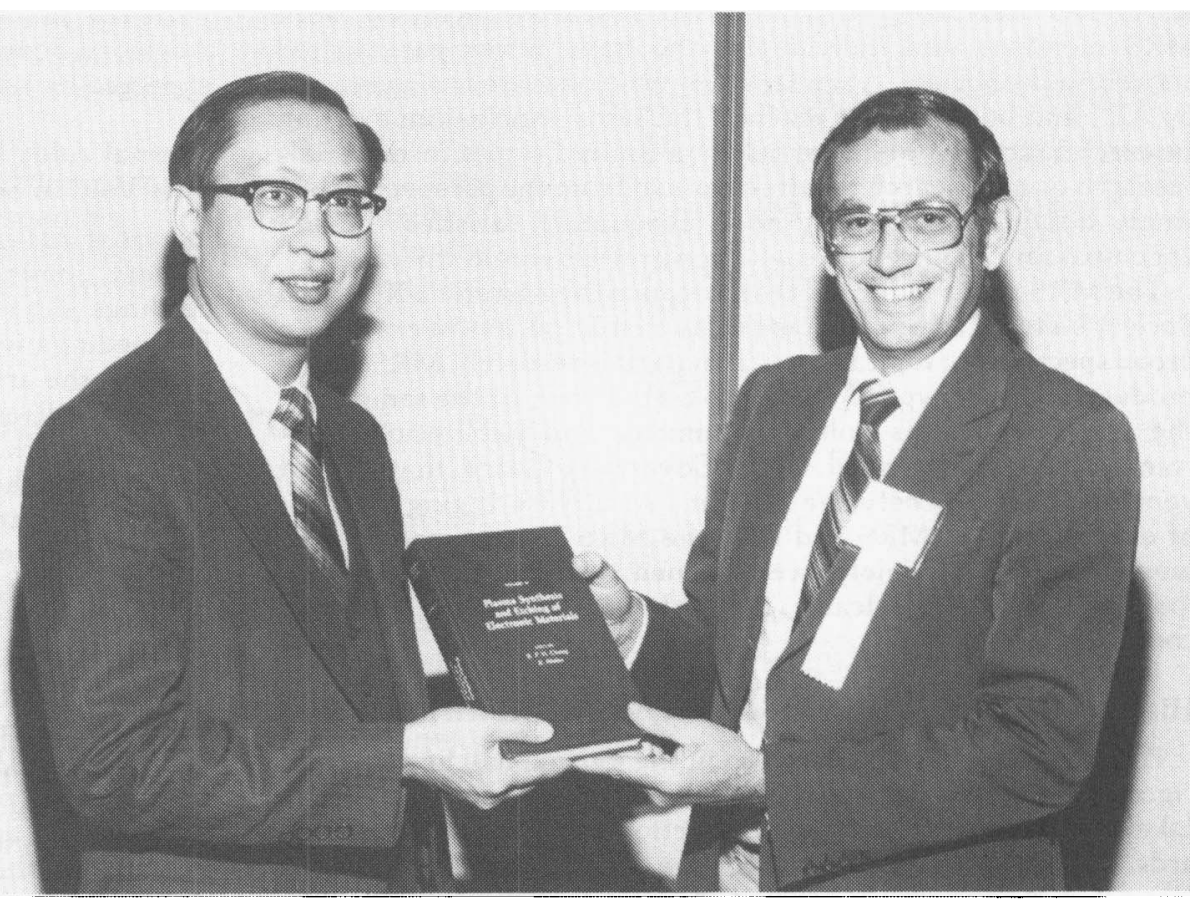

Bob Chang, editor of the first book published by MRS from the 1984 Fall Meeting, receives a copy of his book, Plasma Synthesis and Etching of Electronic Materials, from 1984 Fall Meeting Program Chair Paul Peercy. 